\title{
Central and direct regulation of testicular activity by gonadotropin-inhibitory hormone and its receptor
}

\author{
Takayoshi Ubuka ${ }^{1}$, You Lee Son ${ }^{1}$, Yasuko Tobari ${ }^{1}$, Misato Narihiro' $^{1}$, George E. Bentley ${ }^{2}$, Lance J. Kriegsfeld ${ }^{3}$ \\ and Kazuyoshi Tsutsui ${ }^{1}{ }^{*}$
}

${ }^{1}$ Department of Biology, Center for Medical Life Science, Waseda University, Tokyo, Japan

${ }^{2}$ Department of Integrative Biology, Helen Wills Neuroscience Institute, University of California at Berkeley, Berkeley, CA, USA

${ }^{3}$ Department of Psychology, Helen Wills Neuroscience Institute, University of California at Berkeley, Berkeley, CA, USA

\section{Edited by:}

Gilda Cobellis, Second University of Naples, Italy

Reviewed by:

Rosanna Chianese, Second University of Naples, Italy

Rosaria Meccariello, University of

Naples Parthenope, Italy

\section{*Correspondence:}

Kazuyoshi Tsutsui, Laboratory of

Integrative Brain Sciences,

Department of Biology, Center for

Medical Life Science, Waseda

University, 2-2 Wakamatsu-cho,

Shinjuku-ku, Tokyo 162-8480, Japan

e-mail: k-tsutsui@waseda.jp
Gonadotropin-inhibitory hormone $(\mathrm{Gn} / \mathrm{H})$ was first identified in Japanese quail to be an inhibitor of gonadotropin synthesis and release. GnlH peptides have since been identified in all vertebrates, and all share an LPXRFamide $(X=L$ or $Q)$ motif at their $\mathrm{C}$-termini. The receptor for $\mathrm{GnIH}$ is the G protein-coupled receptor 147 (GPR147), which inhibits cAMP signaling. Cell bodies of $\mathrm{GnlH}$ neurons are located in the paraventricular nucleus (PVN) in birds and the dorsomedial hypothalamic area $(\mathrm{DMH})$ in most mammals. GnlH neurons in the PVN or DMH project to the median eminence to control anterior pituitary function via GPR147 expressed in gonadotropes. Further, $\mathrm{GnIH}$ inhibits gonadotropin-releasing hormone (GnRH)-induced gonadotropin subunit gene transcription by inhibiting the adenylate cyclase/cAMP/PKAdependent ERK pathway in an immortalized mouse gonadotrope cell line ( $L \beta T 2$ cells). $\mathrm{GnIH}$ neurons also project to $\mathrm{GnRH}$ neurons that express GPR147 in the preoptic area (POA) in birds and mammals. Accordingly, GnlH can inhibit gonadotropin synthesis and release by decreasing the activity of $\mathrm{GnRH}$ neurons as well as by directly inhibiting pituitary gonadotrope activity. GnIH and GPR147 can thus centrally suppress testosterone secretion and spermatogenesis by acting in the hypothalamic-pituitary-gonadal axis. GnlH and GPR147 are also expressed in the testis of birds and mammals, possibly acting in an autocrine/paracrine manner to suppress testosterone secretion and spermatogenesis. GnIH expression is also regulated by melatonin, stress, and social environment in birds and mammals. Accordingly, the GnIH-GPR147 system may play a role in transducing physical and social environmental information to regulate optimal testicular activity in birds and mammals. This review discusses central and direct inhibitory effects of GnIH and GPR147 on testosterone secretion and spermatogenesis in birds and mammals.

Keywords: gonadotropin-inhibitory hormone, GPR147, gonadotropins, testosterone, spermatogenesis, melatonin, stress, social environment

\section{INTRODUCTION}

Testicular activity is under the control of the gonadotropins, luteinizing hormone (LH) and follicle-stimulating hormone (FSH), which are synthesized in the anterior pituitary gland. LH and FSH are released into the circulation and activate their receptors expressed on Leydig cells and Sertoli cells, respectively, to stimulate testosterone secretion and spermatogenesis in the testis (1) (Figure 1). Spermatogenesis is a conserved process in vertebrate testis, where spermatogonia develop into spermatocytes that undergo meiosis to produce spermatids that enter spermiogenesis and undergo a morphological transformation into spermatozoa (2) (Figure 1). The process of germ cell development and maturation can be divided into two distinct patterns in vertebrates, one in anamniotes (fish and amphibia) and the other in amniotes (reptiles, birds, and mammals). In anamniotes, spermatogenesis occurs in spermatocysts, which for most species develop in seminiferous lobules. In amniotes, spermatogenesis occurs in seminiferous tubules that possess a permanent population of Sertoli cells, which support spermatogenesis and spermiogenesis, and spermatogonia, and act as a germ cell reservoir for succeeding bouts of spermatogenic activity (2) (Figure 1).

The hypothalamic decapeptide gonadotropin-releasing hormone $(\mathrm{GnRH})$ is the primary factor that regulates gonadotropin secretion. GnRH is produced in the preoptic area (POA) and released at the median eminence to stimulate gonadotropin secretion from the pituitary (Figure 1). GnRH was first identified in mammals $(6,7)$ and subsequently in birds $(8,9)$ and other vertebrates. Testicular steroids and inhibin can modulate gonadotropin secretion by negative feedback. Although dopamine has been reported as an inhibitor of gonadotropin secretion in several fishes (10), no hypothalamic neuropeptide inhibitor of gonadotropin secretion was known in vertebrates. In 2000, a hypothalamic neuropeptide was shown to inhibit gonadotropin release from the cultured quail anterior pituitary gland and it was named gonadotropin-inhibitory hormone [GnIH; (11)] (Figure 1). GnIH was originally identified in birds (11) and subsequently in various vertebrates including mammals [for reviews, see Ref. (12-21)] (Table 1). Based on extensive studies on birds and mammals, 


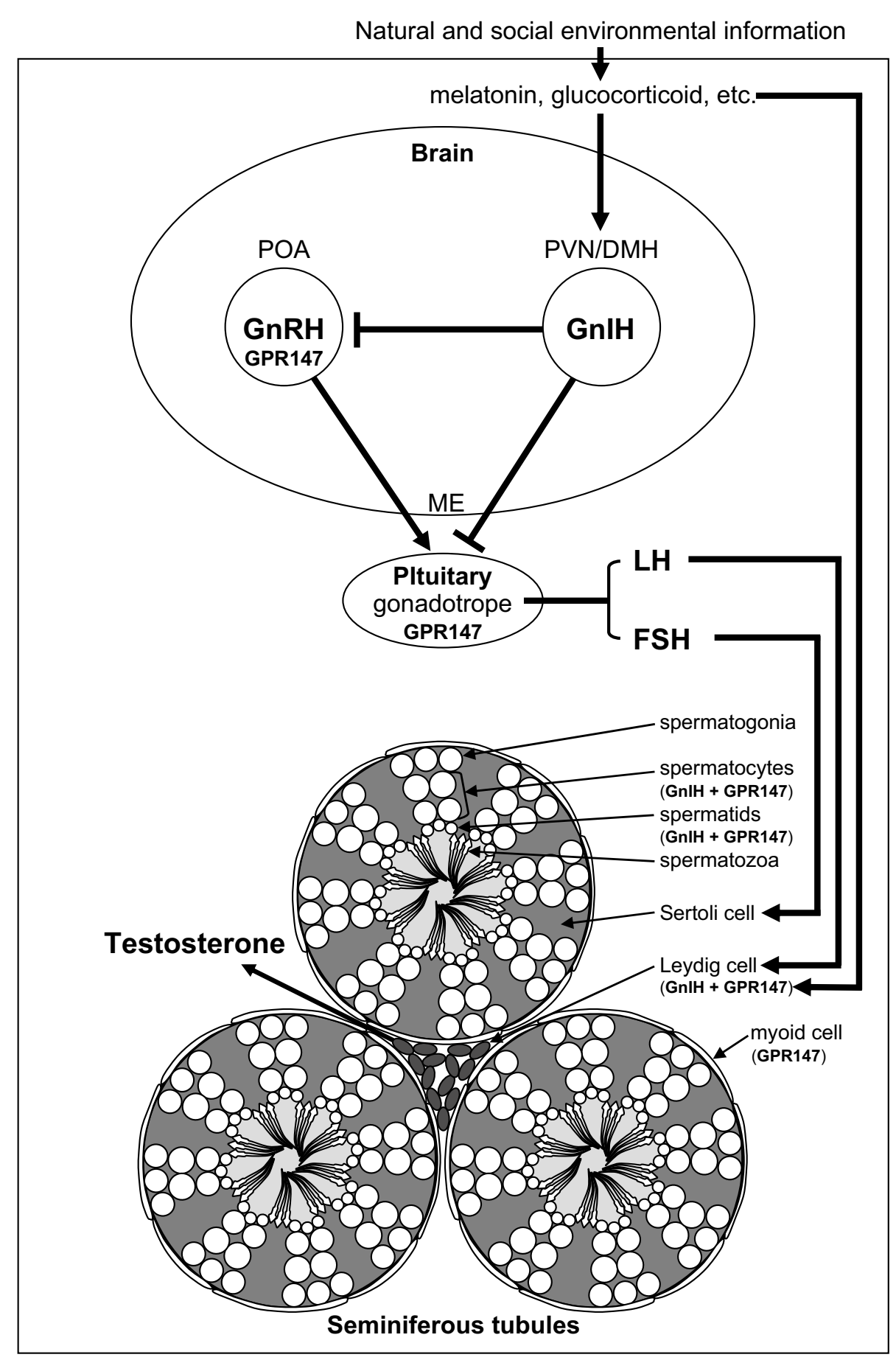

FIGURE 1 | Schematic model of central and direct actions of GnIH on testicular activity in birds and mammals. Neuronal cell bodies expressing gonadotropin-inhibitory hormone $(\mathrm{GnlH})$ are located in the paraventricular nucleus (PVN) in birds and the dorsomedial hypothalamic area (DMH) in mammals. GnIH neurons in the PVN or DMH project to the median eminence (ME) to control anterior pituitary function via $\mathrm{GnIH}$ receptor (GPR147) expressed in gonadotropes. GnIH neurons also project to gonadotropin-releasing hormone $(\mathrm{GnRH})$ neurons that express GPR147 in the preoptic area (POA) in birds and mammals. Accordingly, $\mathrm{GnIH}$ may inhibit gonadotropin [luteinizing hormone $(\mathrm{LH})$ and follicle-stimulating hormone (FSH)] synthesis and release by decreasing the activity of $\mathrm{GnRH}$ neurons as well as directly inhibiting pituitary gonadotrope function. GnIH and/or GPR147 are also expressed in the testis of birds $(3,4)$ and mammals $(5)$, possibly acting in an autocrine/paracrine manner to suppress testosterone secretion and spermatogenesis. GnIH and GPR147 can thus suppress testosterone secretion and spermatogenesis by acting at all levels of the hypothalamic-pituitary-testicular axis. GnIH expression is further regulated by melatonin, glucocorticoids, and the social environment in birds and mammals suggesting an important role in appropriate regulation of testicular activity seasonally, during times of stress and when interacting with conspecifics in birds and mammals. 
Table 1 | Amino acid sequences of avian and mammalian GnIHs [LPXRFamide ( $X=L$ or $Q$ ) peptides].

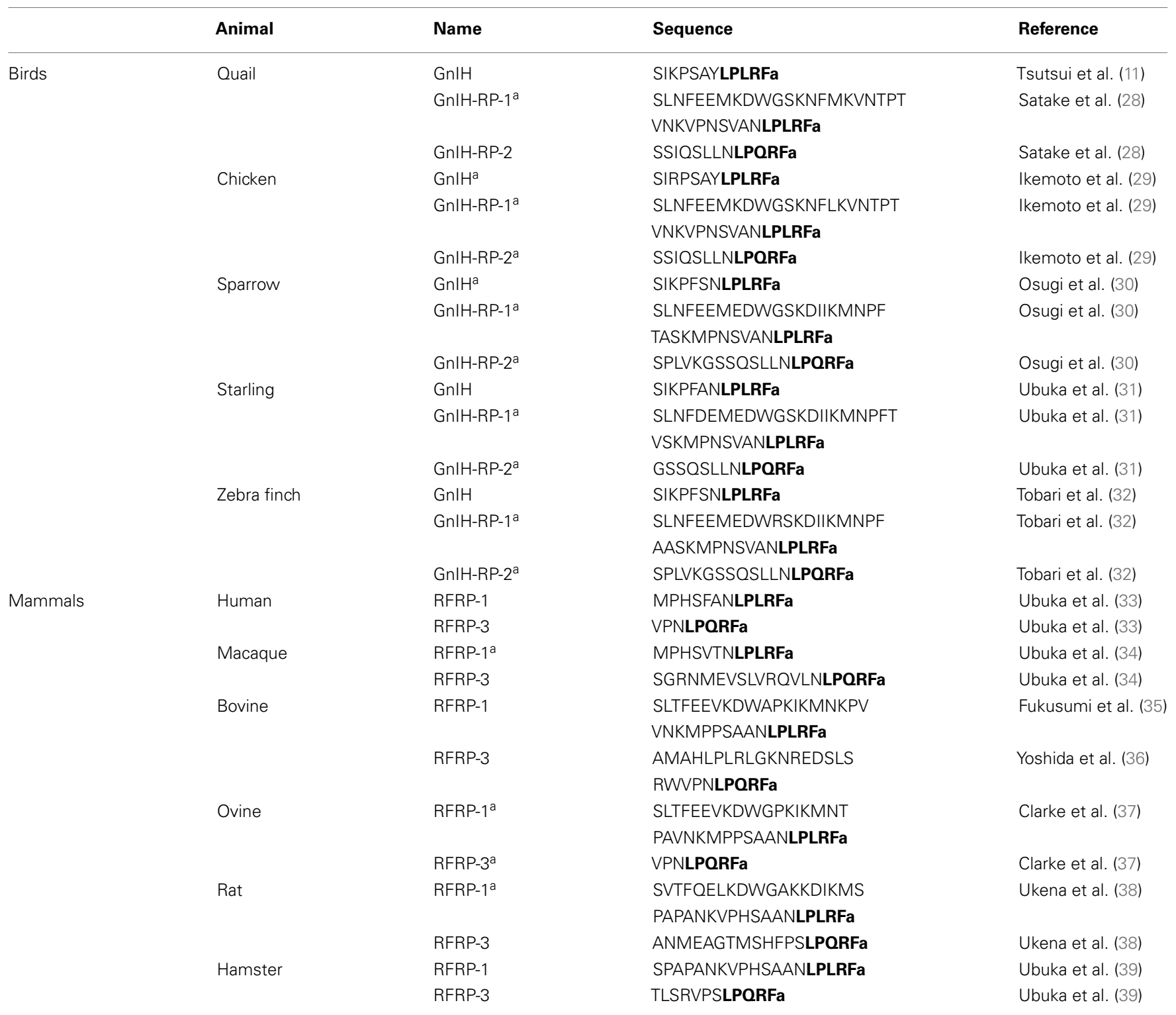

a Putative peptides. The $C$-terminal LPXRFamide $(X=L$ or $Q)$ motifs are shown in bold.

it appeared that $\mathrm{GnIH}$ can inhibit gonadotropin secretion by decreasing the activity of GnRH neurons as well as directly inhibiting pituitary gonadotropes [for reviews, see Ref. (12-21)]. GnIH and its receptor (GPR147) are also expressed in the gonads of birds $(3,4,22,23)$ and mammals $(5,24-26)$ including humans (27), possibly acting in an autocrine/paracrine manner (Figure 1). This review summarizes possible central and direct effects of $\mathrm{GnIH}$ and GPR147 on testosterone secretion and spermatogenesis in birds and mammals.

\section{GnIH RECEPTOR AND CELL SIGNALING}

Bonini et al. (40) have identified two $G$ protein-coupled receptors (GPCRs) for neuropeptide FF (NPFF), which has a PQRFamide motif at its C-terminus, and named them as NPFF1 (identical to GPR147) and NPFF2 (identical to GPR74). Hinuma et al.
(41) have reported a specific receptor for mammalian $\mathrm{GnIH}$, RFamide-related peptide (RFRP), and named it OT7T022, which was identical to NPFF1 (GPR147). The binding affinities for GPR147 and GPR74 and the signal transduction pathway were examined, using various analogs of GnIHs (RFRPs) and NPFF. RFRPs showed a higher affinity for GPR147, whereas NPFF had potent agonistic activity for GPR74 (40, 42). Accordingly, GPR147 (NPFF1, OT7T022) was suggested to be the principal receptor for GnIH (RFRP). It was also shown that GnIHs (RFRPs) suppress cAMP production in Chinese hamster ovarian cells transfected with GPR147 cDNA, suggesting that GPR147 couples to $\mathrm{G}_{\alpha \mathrm{i}}$ protein (41).

Yin et al. (43) identified GnIH receptor (GPR147) in the quail diencephalon and characterized its binding activity. First, a cDNA encoding a putative GPR147 was cloned using PCR primers 
designed from the sequence of the receptor for RFRPs. The crude membrane fraction of COS-7 cells transfected with the putative GPR147 cDNA specifically bound GnIH, GnIH-related peptides (-RPs), and RFRPs, which have an LPXRFamide (X=L or $\mathrm{Q})$ motif at their C-termini, in a concentration-dependent manner (43). In contrast, C-terminal non-amidated GnIH failed to bind the receptor. Accordingly, the C-terminal LPXRFamide (X $=\mathrm{L}$ or Q) motif seems to be critical for its binding to GPR147 (43). It was suggested that there is no functional difference among $\mathrm{GnIH}$ and GnIH-RPs because GPR147 bound GnIH and GnIH-RPs with similar affinities (43). Further studies are required to investigate if $\mathrm{GnIH}$ and GnIH-RPs work additively or synergistically to achieve their effects on the target cells that express GnIH-R.

Ikemoto and Park (29) cloned GnIH, GPR147, and GPR74 cDNAs in the chicken. GPR147 cDNA was expressed only in the brain and pituitary, where GnIH may act directly on gonadotropes. On the other hand, GPR74 cDNA was ubiquitously expressed in various tissue and organs where $\mathrm{GnIH}$ action is unknown. Quail $\mathrm{GnIH}$ and putative chicken $\mathrm{GnIH}$ inhibited $\mathrm{G}_{\alpha \mathrm{i} 2}$ mRNA expression in COS-7 cells transiently transfected with chicken GPR147 or GPR74. However, the effect of GnIHs on the inhibition of $\mathrm{G}_{\alpha \mathrm{i} 2}$ mRNA expression in COS-7 cells was about 100-fold stronger in COS-7 cells transfected with GPR147 than GPR74 (29). These results further suggest that GPR147 is the principal receptor for GnIH in birds as in mammals.

To further investigate the intracellular signaling pathway responsible for the actions of $\mathrm{GnIH}$ and its possible interaction with GnRH, Son et al. (44) used a mouse gonadotrope cell line, L $\beta$ T2. Using this cell line, this group established that mouse GnIHs (mRFRPs) effectively inhibit GnRH-induced cAMP signaling, indicating that mouse GnIHs (mRFRPs) function as inhibitors of adenylate cyclase (AC). They further showed that mouse GnIHs (mRFRPs) inhibit GnRH-stimulated ERK phosphorylation and gonadotropin subunit gene transcription. The results indicated that mouse GnIHs (mRFRPs) inhibit GnRHinduced gonadotropin subunit gene transcriptions by inhibiting AC/cAMP/PKA-dependent ERK activation in L $\beta$ T2 cells (44).

Shimizu and Bédécarrats (45) showed that GPR147 mRNA levels fluctuate in an opposite manner to GnRH-receptor-III, a pituitary specific form of $\mathrm{GnRH}$ receptor (GnRH-R), in the chicken $(46,47)$ according to reproductive stages. They demonstrated that the chicken GPR147 inhibits cAMP production, most likely by coupling to $G_{\alpha \mathrm{i}}$. This inhibition significantly reduces $\mathrm{GnRH}$-induced cAMP responsive element activation in a dosedependent manner, and the ratio of $\mathrm{GnRH} / \mathrm{GnIH}$ receptors was a significant modulatory factor. From these results they proposed that in avian species, sexual maturation is characterized by a change in $\mathrm{GnIH} / \mathrm{GnRH}$ receptor ratio, changing pituitary sensitivity from $\mathrm{GnIH}$ inhibition of, to $\mathrm{GnRH}$ stimulation of, gonadotropin secretion (45).

\section{SUPPRESSION OF TESTICULAR ACTIVITY BY GnIH INHIBITION OF GONADOTROPIN SECRETION}

Gonadotropin-inhibitory hormone precursor mRNA was first localized by Southern blot analysis of the RT-PCR products in the quail brain. Within the samples from telencephalon, diencephalon, mesencephalon, and cerebellum, GnIH precursor mRNA was only expressed in the diencephalon (28). In situ hybridization for GnIH precursor mRNA showed that cells expressing GnIH mRNA are clustered in the paraventricular nucleus (PVN) in the hypothalamus (48). Immunohistochemistry using an antibody raised against avian $\mathrm{GnIH}$ has revealed that GnIH-ir neurons are clustered in the PVN in quail and other birds $(11,30-32,49,50)$ (Figure 1).

In mammals, GnIH (RFRP) precursor mRNA is expressed in the dorsomedial hypothalamic area (DMH) in mouse and hamster brains, as visualized by in situ hybridization $(39,51)$ (Figure 1). Mammalian GnIH (RFRP) precursor mRNA is expressed in the periventricular nucleus (PerVN), and in the area between the dorsomedial nucleus (DMN) and the ventromedial nucleus (VMN) of the hypothalamus in the rat brain $(41,52)$. GnIH (RFRP) mRNA expressing neuronal cell bodies are localized in the intermediate periventricular nucleus (IPe) of the hypothalamus in the macaque (34), and in the DMN and PVN in the sheep (37).

Immunohistochemical studies using light and confocal microscopy showed that GnIH (RFRP)-ir axon terminals are in close contact with GnRH neurons in birds $(50)$, rodents $(39,51)$, monkeys (34), and humans (33) (Figure 1), suggesting direct inhibition of GnRH cells by GnIH. Ubuka et al. (31) investigated the interaction of GnIH neuronal fibers with GnRH neurons in the European starling brain. Birds possess at least two forms of $\mathrm{GnRH}$ in their brains. One form is GnRH1 which is thought to be released at the median eminence to stimulate the secretion of gonadotropins from the anterior pituitary $(8,9,53-$ 57). The second form of GnRH, GnRH2 $(58,59)$, is thought to influence reproductive behaviors in birds (60) and mammals $(61,62)$. Double-label immunocytochemistry showed GnIH axon terminals on GnRH1 and GnRH2 neurons in the songbird brain $(31,50,63)$ suggesting regulation of both gonadotropin secretion and reproductive behavior. In situ hybridization of starling GPR147 mRNA combined with GnRH immunocytochemistry further showed the expression of GPR147 mRNA in GnRH1 and GnRH2 neurons (31). Similarly, in Siberian hamsters, double-label immunocytochemistry revealed $\mathrm{GnIH}$ axon terminals on GnRH neurons, with a subset of GnRH neurons expressing GPR147 (39). Using immunomagnetic purification of GnRH cells, single-cell nested RT-PCR, and in situ hybridization, Rizwan et al. (64) showed that 33\% of GnRH neurons expressed GPR147, whereas GPR74 was not expressed in either population in mice.

Central administration of $\mathrm{GnIH}$ inhibits the release of gonadotropins in white-crowned sparrows (65), Syrian hamsters (51), rats (66), and Siberian hamsters (39) as does peripheral administration of $\mathrm{GnIH}(30,51,67)$. Direct application of mouse GnIH (RFRP-3) to GnRH cells in mouse brain slices decreased firing rate in a subpopulation of GnRH cells (68). GnIH (RFRP3) also inhibited firing of kisspeptin-activated vGluT2 (vesicular glutamate transporter 2)-GnRH neurons as well as of kisspeptininsensitive GnRH neurons (69). These findings suggest that $\mathrm{GnIH}$ may inhibit gonadotropin secretion by decreasing the activity of $\mathrm{GnRH}$ neurons in addition to directly regulating pituitary gonadotropes in birds and mammals (Figure 1). Importantly, the inhibitory action of GnIH (RFRP-1 and RFRP-3) was only observed in reproductively active long-day (LD) Siberian hamsters 
that have high gonadotropin concentration, and GnIH (RFRP-1 and RFRP-3) increased basal gonadotropin concentration in reproductively inactive short-day (SD) hamsters (39).

Given the existence of $\mathrm{GnIH}$-ir fibers at the median eminence in birds $(11,30,31,48,50)$, much of the work to date has focused on the role of $\mathrm{GnIH}$ in pituitary gonadotrope regulation (Figure 1). As indicated previously, GnIH suppresses gonadotropin synthesis and/or release from cultured quail and chicken anterior pituitary gland $(11,70)$. In mammals, abundant GnIH (RFRP)-ir fibers are observed in the median eminence of sheep (37), macaque (34), hamsters (71), and humans (33). As in birds, mammalian $\mathrm{GnIH}$ (RFRP-3) inhibits gonadotropin synthesis and/or release from cultured pituitaries in sheep (72) and cattle (73). Peripheral administration of $\mathrm{GnIH}$ (RFRP-3) also inhibits gonadotropin release in sheep (37), rats (74), and cattle (73), suggesting actions on the pituitary. Finally, GPR147 mRNA is expressed in gonadotropes in the human pituitary (33). Together, these findings suggest that GnIH and RFRP-3 act directly on the pituitary to inhibit gonadotropin secretion, at least in these avian and mammalian species (Figure 1).

Further evidence for a direct action of GnIH on the pituitary comes from a study by Sari et al. (72) where they investigated the effects of GnIH (RFRP-3) on the expression of gonadotropin $\beta$ subunit genes in ovine pituitary cells. GnRH or vehicle pulses were given to pituitary cells every $8 \mathrm{~h}$ for $24 \mathrm{~h}$ with and without $\mathrm{GnIH}$ (RFRP-3) treatment. GnIH (RFRP-3) reduced LH and FSH secretion stimulated by GnRH. GnIH (RFRP-3) also reduced GnRHstimulated $\mathrm{LH} \beta$ and $\mathrm{FSH} \beta$ subunit gene expressions. Further, GnIH (RFRP-3) abolished GnRH-stimulated phosphorylation of ERK in the pituitary (72).

To establish whether or not GnIH is endogenously released into the anterior pituitary, Smith et al. (75) directly measured GnIH (RFRP-3) in hypophyseal portal blood in ewes during the non-breeding (anestrous) season and during the luteal and follicular phases of the estrous cycle in the breeding season. Pulsatile GnIH (RFRP-3) secretion was observed in the portal blood, with pulse amplitude and pulse frequency being higher during the non-breeding season. Additionally, the magnitude of the LH response to GnRH was reduced by GnIH (RFRP-3) administration in hypothalamo-pituitary-disconnected ewes, providing support for important functionality of this pathway. Together, these data provide convincing evidence that GnIH (RFRP-3) is secreted into portal blood to act on pituitary gonadotropes, reducing the action of GnRH in sheep (75).

To further establish the functional significance and mode of action of GnIH, Ubuka et al. (67) investigated the role of GnIH on gonadal development and maintenance in male quail. Continuous peripheral administration of $\mathrm{GnIH}$ to mature birds via osmotic pumps for 2 weeks decreased the expressions of gonadotropin common $\alpha$ and $L H \beta$ subunit mRNAs in a dose-dependent manner. As expected, plasma $\mathrm{LH}$ and testosterone concentrations were also decreased dose dependently. Administration of $\mathrm{GnIH}$ to mature birds further induced testicular apoptosis, primarily observed in Sertoli cells, spermatogonia, and spermatocytes, and decreased spermatogenic activity in the testis, either through direct actions of $\mathrm{GnIH}$ at the level of the gonads (see below) or through decreased gonadotropin and testosterone concentrations. In immature birds, daily peripheral administration of $\mathrm{GnIH}$ for 2 weeks suppressed normal testicular growth and the rise in plasma testosterone concentrations. These results indicate that $\mathrm{GnIH}$ inhibits testicular development and maintenance either through decreased gonadotropin synthesis and release or via direct actions on the testes (67) (Figure 1).

\section{GnIH AND GnIH RECEPTOR IN THE TESTIS}

Vertebrate gonads are known to express many "neuropeptides." Bentley et al. (3) demonstrated the expression of $\mathrm{GnIH}$ and its receptor in the avian reproductive system, including the gonads and accessory reproductive organs of Passeriform and Galliform birds. Binding sites for $\mathrm{GnIH}$ were identified via receptor fluorography in the interstitial layer and seminiferous tubules of the testis. Immunocytochemistry detected GnIH in testicular interstitial cells and germ cells, and pseudostratified columnar epithelial cells in the epididymis. In situ hybridization for GPR147 mRNA produced a strong reaction product in the germ cells and interstitium in the testes as well as pseudostratified columnar epithelial cells. The distribution of $\mathrm{GnIH}$ and its receptor suggested a potential for autocrine/paracrine regulation of testosterone production and germ cell differentiation and maturation in birds (3) (Figure 1).

To examine the functional significance of these findings, McGuire and Bentley (4) investigated the action of GnIH and $\mathrm{GnIH}$ receptor in the testis of house sparrow. GnIH precursor mRNA was expressed in the interstitium and GPR147 mRNA was expressed in the interstitium and spermatocytes (Figure 1). $\mathrm{GnIH}$ significantly decreased the testosterone secretion from gonadotropin-stimulated testis cultures (4), suggesting that $G n I H$ and GPR147 are expressed in Leydig cells to reduce the effect of $\mathrm{LH}$ on testosterone secretion in an autocrine/paracrine manner (Figure 1).

To examine the generality of the findings in birds, Zhao et al. (5) examined GnIH (RFRP), GPR147, and GPR74 expression in the testes of Syrian hamsters. GnIH (RFRP) expression was observed in spermatocytes and in round to early elongated spermatids. GPR147 protein was observed in myoid cells in all stages of spermatogenesis, pachytene spermatocytes, maturation division spermatocytes, and in round and late elongated spermatids. GPR74 proteins only appeared in late elongated spermatids. As in birds, these findings suggest a possible autocrine and/or paracrine role for GnIH (RFRP) in Syrian hamster testis, potentially contributing to the differentiation of spermatids during spermiogenesis (5) (Figure 1).

Anjum et al. (76) investigated the changes in $\mathrm{GnRH}, \mathrm{GnIH}$, and GnRH-R in the testis from birth to senescence in mice. They found that increased staining of testicular GnRH-R coincided with increased steroidogenic activity during pubertal and adult stages, whereas decreased staining coincided with decreased steroidogenic activity during senescence, suggesting a putative role of $\mathrm{GnRH}$ during testicular pubertal development and senescence. The significant decline in GnRH-R during senescence was suggested to be due to a significant increase in $\mathrm{GnIH}$ synthesis during senescence. These observations provide new perspectives in the autocrine/paracrine control of testicular activity by $\mathrm{GnRH}$ and GnIH (76). 


\section{REGULATION OF GnIH GENE EXPRESSION BY MELATONIN}

Investigating the regulatory mechanisms of $\mathrm{GnIH}$ expression has important implications for understanding the physiological role of the GnIH system. Photoperiodic mammals regulate reproductive activities according to the annual cycle of changes in nocturnal secretion of melatonin (77). Despite the accepted dogma that birds do not use seasonal changes in melatonin secretion to time their reproductive effort $(78,79)$, there is some evidence that melatonin is involved in the regulation of several seasonal processes, including gonadal activity, gonadotropin secretion, and timing of egg-laying (80-83). Therefore, Ubuka et al. (84) investigated the action of melatonin on the expression of GnIH in quail, a highly photoperiodic bird species. Because the pineal gland and eyes are the major sources of melatonin in quail (85), Ubuka et al. (84) tested the effects of pinealectomy (Px) combined with orbital enucleation (Ex) (Px plus Ex) and melatonin administration on the expression of $\mathrm{GnIH}$ precursor mRNA and GnIH peptide. Px plus Ex decreased the expression of GnIH precursor mRNA and the content of mature GnIH peptide in the hypothalamus; melatonin administration caused a dose-dependent increase in GnIH precursor mRNA and $\mathrm{GnIH}$ peptide. Additionally, $\mathrm{Mel}_{1 c} \mathrm{mRNA}$, a melatonin receptor subtype, was expressed in GnIH-ir neurons in the PVN. Melatonin receptor autoradiography further revealed the binding of melatonin in the PVN. The results suggested that melatonin acts directly on $\mathrm{GnIH}$ neurons through its receptor to induce expression of $\mathrm{GnIH}$ (84) (Figure 1). In agreement with this possibility, a later study showed that melatonin can stimulate $\mathrm{GnIH}$ release from the quail hypothalamus (86).

Opposite action of melatonin on the inhibition of $\mathrm{GnIH}$ (RFRP) expression was shown in Syrian and Siberian hamsters, both photoperiodic mammals $(39,87,88)$. GnIH (RFRP) mRNA levels and the number of GnIH (RFRP)-ir cell bodies were reduced in sexually quiescent Syrian and Siberian hamsters acclimated to SD photoperiod, compared to sexually active animals maintained under $\mathrm{LD}$ photoperiod. The photoperiodic effects on $\mathrm{GnIH}$ (RFRP) expression were abolished in Px hamsters and injections of LD hamsters with melatonin reduced the expression of $\mathrm{GnIH}$ (RFRP) to SD levels $(39,87)$. There are also reports showing that the expression of GnIH (RFRP) is regulated by melatonin and season in sheep $(89,90)$ and rats $(91)$. These results demonstrate that as in quail, GnIH (RFRP), expression is photoperiodically modulated via a melatonin-dependent process in mammals (Figure 1).

Given the localization of GnIH in gonadal tissue, McGuire et al. (23) investigated the possibility that melatonin affects sex steroid secretion and GnIH expression in the gonads of European starlings. Starling gonads expressed mRNAs for GnIH, GPR147, and melatonin receptors $\left(\mathrm{Mel}_{1 b}\right.$ and $\left.\mathrm{Mel}_{1 c}\right)$. GnIH and GPR147 expression in the testes was relatively low during the breeding season. The expression levels of $\mathrm{Mel}_{1 b}$ and $\mathrm{Mel}_{1 c}$ were correlated with $\mathrm{GnIH}$ and GPR147 expression, and melatonin up-regulated the expression of GnIH mRNA in starling gonads before the breeding season. GnIH and melatonin significantly decreased the testosterone secretion from gonadotropin-stimulated testes in vitro prior to, but not during, the breeding season. Thus, local inhibition of testosterone secretion appears to be regulated seasonally at the level of the testis by a mechanism involving melatonin and gonadal GnIH in birds (23) (Figure 1).

\section{BY STRESS}

Stress can lead to reproductive dysfunction across vertebrates (92). To explore whether or not stress might act to inhibit reproduction through the GnIH system, Calisi et al. (93) examined the effects of capture-handling stress on GnIH expression in male and female adult house sparrows. More $\mathrm{GnIH}$-positive neurons were observed in fall birds versus those sampled in the spring, and GnIH-positive neurons were increased significantly by capture-handling stress in spring birds. These data imply that stress influences GnIH early during the breeding season, but not after birds have committed to reproduction (93) (Figure 1). McGuire et al. (94) tested the hypothesis that the gonads are directly influenced by stress hormones, showing that physiologically relevant concentrations of corticosterone can directly up-regulate $\mathrm{GnIH}$ expression and decrease the testosterone secretion from gonadotropin-stimulated testes prior to the breeding season (Figure 1). These findings suggest that, stress acts on both central and gonadal GnIH cell populations to inhibit reproductive function.

In agreement with the findings in house sparrows, Kirby et al. (95) showed that both acute and chronic immobilization stress lead to an up-regulation of the expression of GnIH (RFRP) in the DMH of adult male rats associated with the inhibition of downstream hypothalamic-pituitary-testicular activity. Adrenalectomy blocked the stress-induced increase in GnIH (RFRP) expression. Immunohistochemistry revealed that $53 \%$ of GnIH (RFRP) cells express receptors for glucocorticoids, suggesting that adrenal glucocorticoids act directly on GnIH (RFRP) cells to increase GnIH expression. Together, these data suggest that $\mathrm{GnIH}$ is an important integrator of stress-induced suppression of reproductive function (95) (Figure 1).

Son et al. investigated the mechanism by which glucocorticoids influence GnIH gene expression. As in sparrows and rats, GR mRNA was expressed in GnIH neurons in the PVN of quail suggesting direct modulation of $\mathrm{GnIH}$ in this species. Although acute corticosterone treatment had no effect on GnIH mRNA expression, chronic treatment with corticosterone increased $\mathrm{G} n I H$ mRNA expression in the quail diencephalon. Using a rat $\mathrm{GnIH}$ (RFRP)-expressing neuronal cell line, the authors confirmed the co-expression of GR mRNA and established that continuous corticosterone treatment increased GnIH (RFRP) mRNA expression. They further demonstrated that corticosterone directly regulates $G n I H$ gene transcription by recruitment of GR to its promoter at the glucocorticoid responsive element (GRE) (You Lee Son, Takayoshi Ubuka, Narihiro Misato, Yujiro Fukuda, Itaru Hasunuma, Kazutoshi Yamamoto, and Kazuyoshi Tsutsui, unpublished observation) (Figure 1).

\section{BY SOCIAL INTERACTION}

To examine the impact of mating competition on GnIH, Calisi et al. (96) manipulated nesting opportunities for pairs of European starlings and examined brain GnIH mRNA and GnIH content as well as GnRH content. By limiting the number of nest boxes and thus the number of social pairing and nesting opportunities, 
they observed that birds with nest boxes had significantly fewer numbers of GnIH-producing cells than those without nest boxes and this relationship reversed once eggs had been laid. On the other hand, GnRH content did not vary with nest box ownership. These data suggest that GnIH may serve as a modulator of reproductive function in response to social environment (96) (Figure 1).

It is known that the presence of a female bird as well as copulation rapidly decrease plasma testosterone concentrations in male quail $(97,98)$. Tobari et al. sought to explore the neurochemical mechanism translating social stimuli into reproductive physiology and behavior. They observed that visual presentation of a female quail decreased plasma LH and testosterone concentrations and this effect was likely to be caused by activation of GnIH neurons in the male quail hypothalamus (Yasuko Tobari, You Lee Son, Takayoshi Ubuka, Yoshihisa Hasegawa, Kazuyoshi Tsutsui, unpublished observation) (Figure 1). Together with the findings in starlings, these findings point to a prominent role for GnIH in mediating the impact of social stimuli on the reproductive axis.

\section{SUMMARY}

As described in the present review, GnIH, acting via GPR147, can suppress the testosterone secretion and spermatogenesis by acting at all levels of the hypothalamic-pituitary-gonadal axis of birds and mammals. GPR147 is expressed in GnRH cells, pituitary gonadotropes, and at the level of the testis and studies described herein at the organismal and cell culture levels provide functional evidence for control at each locus. Additionally, GnIH expression is regulated by melatonin, glucocorticoids, and the social environment. Together, these findings highlight a prominent role for GnIH-GPR147 in integrating physical and social environmental information to regulate reproductive activities appropriately in birds and mammals.

\section{ACKNOWLEDGMENTS}

This work was supported by Grants-in-Aid for Scientific Research from the Ministry of Education, Science and Culture, Japan (22132004 and 22227002 to Kazuyoshi Tsutsui), NIH grant HD050470 (Lance J. Kriegsfeld) and NSF grant IOS-1257638 (Lance J. Kriegsfeld) and NSF IOS-1122044 (George E. Bentley).

\section{REFERENCES}

1. Shalet SM. Normal testicular function and spermatogenesis. Pediatr Blood Cancer (2009) 53:285-8. doi:10.1002/pbc.22000

2. Pudney J. Spermatogenesis in nonmammalian vertebrates. Microsc Res Tech (1995) 32:459-97. doi:10.1002/jemt.1070320602

3. Bentley GE, Ubuka T, McGuire NL, Chowdhury VS, Morita Y, Yano T, et al. Gonadotropin-inhibitory hormone and its receptor in the avian reproductive system. Gen Comp Endocrinol (2008) 156:34-43. doi:10.1016/j.ygcen. 2007.10.003

4. McGuire NL, Bentley GE. A functional neuropeptide system in vertebrate gonads: gonadotropin-inhibitory hormone and its receptor in testes of fieldcaught house sparrow (Passer domesticus). Gen Comp Endocrinol (2010) 166:565-72. doi:10.1016/j.ygcen.2010.01.010

5. Zhao S, Zhu E, Yang C, Bentley GE, Tsutsui K, Kriegsfeld LJ. RFamiderelated peptide and messenger ribonucleic acid expression in mammalian testis: association with the spermatogenic cycle. Endocrinology (2010) 151:617-27. doi:10.1210/en.2009-0978

6. Matsuo H, Baba Y, Nair RM, Arimura A, Schally AV. Structure of the porcine LH- and FSH-releasing hormone. I. The proposed amino acid sequence.
Biochem Biophys Res Commun (1971) 43:1334-9. doi:10.1016/S0006-291X(71) 80019-0

7. Burgus R, Butcher M, Amoss M, Ling N, Monahan M, Rivier J, et al. Primary structure of the ovine hypothalamic luteinizing hormone-releasing factor (LRF). Proc Natl Acad Sci U S A (1972) 69:278-82. doi:10.1073/pnas. 69.1.278

8. King JA, Millar RP. Structure of chicken hypothalamic luteinizing hormonereleasing hormone. I. Structural determination on partially purified material. J Biol Chem (1982) 257:10722-8.

9. Miyamoto K, Hasegawa Y, Minegishi T, Nomura M, Takahashi Y, Igarashi $\mathrm{M}$, et al. Isolation and characterization of chicken hypothalamic luteinizing hormone-releasing hormone. Biochem Biophys Res Commun (1982) 107:820-7. doi:10.1016/0006-291X(82)90596-4

10. Zohar Y, Muñoz-Cueto JA, Elizur A, Kah O. Neuroendocrinology of reproduction in teleost fish. Gen Comp Endocrinol (2010) 165:438-55. doi:10.1016/j. ygcen.2009.04.017

11. Tsutsui K, Saigoh E, Ukena K, Teranishi H, Fujisawa Y, Kikuchi M, et al. A novel avian hypothalamic peptide inhibiting gonadotropin release. Biochem Biophys Res Commun (2000) 275:661-7. doi:10.1006/bbrc.2000.3350

12. Bentley GE, Tsutsui K, Kriegsfeld LJ. Recent studies of gonadotropin-inhibitory hormone $(\mathrm{GnIH})$ in the mammalian hypothalamus, pituitary and gonads. Brain Res (2010) 1364:62-71. doi:10.1016/j.brainres.2010.10.001

13. Kriegsfeld LJ, Gibson EM, Williams WP III, Zhao S, Mason AO, Bentley GE, et al. The roles of RFamide-related peptide- 3 in mammalian reproductive function and behaviour. J Neuroendocrinol (2010) 22:692-700. doi:10.1111/j.13652826.2010.02031.x

14. Tsutsui K. Review: a new key neurohormone controlling reproduction, gonadotropin-inhibitory hormone $(\mathrm{GnIH})$ : biosynthesis, mode of action and functional significance. Prog Neurobiol (2009) 88:76-88. doi:10.1016/j. pneurobio.2009.02.003

15. Tsutsui K, Bentley GE, Bedecarrats G, Osugi T, Ubuka T, Kriegsfeld LJ. Review: gonadotropin-inhibitory hormone $(\mathrm{GnIH})$ and its control of central and peripheral reproductive function. Front Neuroendocrinol (2010) 31:284-95. doi:10.1016/j.yfrne.2010.03.001

16. Tsutsui K, Bentley GE, Kriegsfeld LJ, Osugi T, Seong JY, Vaudry H. Review: discovery and evolutionary history of gonadotrophin-inhibitory hormone and kisspeptin: new key neuropeptides controlling reproduction. J Neuroendocrinol (2010) 22:716-27. doi:10.1111/j.1365-2826.2010.02018.x

17. Tsutsui K, Ubuka T, Bentley GE, Kriegsfeld LJ. Review: gonadotropininhibitory hormone $(\mathrm{GnIH})$ : discovery, progress and prospect. Gen Comp Endocrinol (2012) 177:305-14. doi:10.1016/j.ygcen.2012.02.013

18. Tsutsui K, Ubuka T, Bentley GE, Kriegsfeld LJ. Review: regulatory mechanisms of gonadotropin-inhibitory hormone $(\mathrm{GnIH})$ synthesis and release in photoperiodic animals. Front Neurosci (2013) 7:60. doi:10.3389/fnins.2013.00060

19. Tsutsui K, Ubuka T. Gonadotropin-inhibitory Hormone. In: Kastin AJ, Vaudry $\mathrm{H}$, editors. Handbook of Biologically Active Peptides. Section on Brain Peptides. London: Academic Press (2012). p. 802-11.

20. Ubuka T, Son YL, Tobari Y, Tsutsui K. Gonadotropin-inhibitory hormone action in the brain and pituitary. Front Endocrinol (Lausanne) (2012) 3:148. doi:10.3389/fendo.2012.00148

21. Ubuka T, Son YL, Bentley GE, Millar RP, Tsutsui K. Gonadotropin-inhibitory hormone $(\mathrm{GnIH}), \mathrm{GnIH}$ receptor and cell signaling. Gen Comp Endocrinol (2013) 190:10-7. doi:10.1016/j.ygcen.2013.02.030

22. Maddineni SR, Ocón-Grove OM, Krzysik-Walker SM, Hendricks GL III, Ramachandran R. Gonadotropin-inhibitory hormone $(\mathrm{GnIH})$ receptor gene is expressed in the chicken ovary: potential role of $\mathrm{GnIH}$ in follicular maturation. Reproduction (2008) 135:267-74. doi:10.1530/REP-07-0369

23. McGuire NL, Kangas K, Bentley GE. Effects of melatonin on peripheral reproductive function: regulation of testicular $\mathrm{GnIH}$ and testosterone. Endocrinology (2011) 152:3461-70. doi:10.1210/en.2011-1053

24. Singh P, Krishna A, Sridaran R, Tsutsui K. Immunohistochemical localization of GnRH and RFamide-related peptide-3 in the ovaries of mice during the estrous cycle. J Mol Histol (2011) 42:371-81. doi:10.1007/s10735011-9340-8

25. Singh P, Krishna A, Tsutsui K. Effects of gonadotropin-inhibitory hormone on folliculogenesis and steroidogenesis of cyclic mice. Fertil Steril (2011) 95:1397-404. doi:10.1016/j.fertnstert.2010.03.052

26. Li X, Su J, Lei Z, Zhao Y, Jin M, Fang R, et al. Gonadotropin-inhibitory hormone $(\mathrm{GnIH})$ and its receptor in the female pig: cDNA cloning, expression in 
tissues and expression pattern in the reproductive axis during the estrous cycle. Peptides (2012) 36:176-85. doi:10.1016/j.peptides.2012.05.008

27. Oishi H, Klausen C, Bentley GE, Osugi T, Tsutsui K, Gilks CB, et al. The human gonadotropin-inhibitory hormone ortholog RFamide-related peptide-3 suppresses gonadotropin-induced progesterone production in human granulosa cells. Endocrinology (2012) 153:3435-45. doi:10.1210/en. 2012-1066

28. Satake H, Hisada M, Kawada T, Minakata H, Ukena K, Tsutsui K. Characterization of a cDNA encoding a novel avian hypothalamic neuropeptide exerting an inhibitory effect on gonadotropin release. Biochem J (2001) 354:379-85. doi:10.1042/0264-6021:3540379

29. Ikemoto T, Park MK. Chicken RFamide-related peptide (GnIH) and two distinct receptor subtypes: identification, molecular characterization, and evolutionary considerations. J Reprod Dev (2005) 51:359-77. doi:10.1262/jrd.16087

30. Osugi T, Ukena K, Bentley GE, O'Brien S, Moore IT, Wingfield JC, et al. Gonadotropin-inhibitory hormone in Gambel's white-crowned sparrow (Zonotrichia leucophrys gambelii): cDNA identification, transcript localization and functional effects in laboratory and field experiments. J Endocrinol (2004) 182:33-42. doi:10.1677/joe.0.1820033

31. Ubuka T, Kim S, Huang YC, Reid J, Jiang J, Osugi T, et al. Gonadotropininhibitory hormone neurons interact directly with gonadotropin-releasing hormone-I and -II neurons in European starling brain. Endocrinology (2008) 149:268-78. doi:10.1210/en.2007-0983

32. Tobari Y, Iijima N, Tsunekawa K, Osugi T, Okanoya K, Tsutsui K, et al. Identification of gonadotropin-inhibitory hormone in the zebra finch (Taeniopygia guttata): peptide isolation, cDNA cloning and brain distribution. Peptides (2010) 31:816-26. doi:10.1016/j.peptides.2010.01.015

33. Ubuka T, Morgan K, Pawson AJ, Osugi T, Chowdhury VS, Minakata H, et al. Identification of human GnIH homologs, RFRP-1 and RFRP-3, and the cognate receptor, GPR147 in the human hypothalamic pituitary axis. PLoS One (2009) 4:e8400. doi:10.1371/journal.pone.0008400

34. Ubuka T, Lai H, Kitani M, Suzuuchi A, Pham V, Cadigan PA, et al. Gonadotropin-inhibitory hormone identification, cDNA cloning, and distribution in rhesus macaque brain. J Comp Neurol (2009) 517:841-55. doi:10.1002/cne.22191

35. Fukusumi S, Habata Y, Yoshida H, Iijima N, Kawamata Y, Hosoya M, et al. Characteristics and distribution of endogenous RFamide-related peptide-1. Biochim Biophys Acta (2001) 1540:221-32. doi:10.1016/S0167-4889(01)00135-5

36. Yoshida H, Habata Y, Hosoya M, Kawamata Y, Kitada C, Hinuma S. Molecular properties of endogenous RFamide-related peptide-3 and its interaction with receptors. Biochim Biophys Acta (2003) 1593:151-7. doi:10.1016/S01674889(02)00389-0

37. Clarke IJ, Sari IP, Qi Y, Smith JT, Parkington HC, Ubuka T, et al. Potent action of RFamide-related peptide-3 on pituitary gonadotropes indicative of a hypophysiotropic role in the negative regulation of gonadotropin secretion. Endocrinology (2008) 149:5811-21. doi:10.1210/en.2008-0575

38. Ukena K, Iwakoshi E, Minakata H, Tsutsui K. A novel rat hypothalamic RFamide-related peptide identified by immunoaffinity chromatography and mass spectrometry. FEBS Lett (2002) 512:255-8. doi:10.1016/S0014-5793(02) 02275-5

39. Ubuka T, Inoue K, Fukuda Y, Mizuno T, Ukena K, Kriegsfeld LJ, et al. Identification, expression, and physiological functions of Siberian hamster gonadotropin-inhibitory hormone. Endocrinology (2012) 153:373-85. doi:10. 1210/en.2011-1110

40. Bonini JA, Jones KA, Adham N, Forray C, Artymyshyn R, Durkin MM, et al. Identification and characterization of two $\mathrm{G}$ protein-coupled receptors for neuropeptide FF. J Biol Chem (2000) 275:39324-31. doi:10.1074/jbc. M004385200

41. Hinuma S, Shintani Y, Fukusumi S, Iijima N, Matsumoto Y, Hosoya M, et al. New neuropeptides containing carboxy-terminal RFamide and their receptor in mammals. Nat Cell Biol (2000) 2:703-8. doi:10.1038/35036326

42. Liu Q, Guan XM, Martin WJ, McDonald TP, Clements MK, Jiang Q, et al. Identification and characterization of novel mammalian neuropeptide FF-like peptides that attenuate morphine-induced antinociception. J Biol Chem (2001) 276:36961-9. doi:10.1074/jbc.M105308200

43. Yin H, Ukena K, Ubuka T, Tsutsui K. A novel G protein-coupled receptor for gonadotropin-inhibitory hormone in the Japanese quail (Coturnix japonica): identification, expression and binding activity. J Endocrinol (2005) 184:257-66. doi:10.1677/joe.1.05926
44. Son YL, Ubuka T, Millar RP, Kanasaki H, Tsutsui K. Gonadotropin-inhibitory hormone inhibits $\mathrm{GnRH}$-induced gonadotropin subunit gene transcriptions by inhibiting AC/cAMP/PKA-dependent ERK pathway in L $\beta$ T2 cells. Endocrinology (2012) 153:2332-43. doi:10.1210/en.2011-1904

45. Shimizu M, Bédécarrats GY. Activation of the chicken gonadotropin-inhibitory hormone receptor reduces gonadotropin releasing hormone receptor signaling. Gen Comp Endocrinol (2010) 167:331-7. doi:10.1016/j.ygcen.2010. 03.029

46. Joseph NT, Morgan K, Sellar R, McBride D, Millar RP, Dunn IC. The chicken type III GnRH receptor homologue is predominantly expressed in the pituitary, and exhibits similar ligand selectivity to the type I receptor. J Endocrinol (2009) 202:179-90. doi:10.1677/JOE-08-0544

47. Shimizu M, Bédécarrats GY. Identification of a novel pituitary-specific chicken gonadotropin-releasing hormone receptor and its splice variants. Biol Reprod (2006) 75:800-8. doi:10.1095/biolreprod.105.050252

48. Ukena K, Ubuka T, Tsutsui K. Distribution of a novel avian gonadotropininhibitory hormone in the quail brain. Cell Tissue Res (2003) 312:73-9. doi:10.1007/s00441-003-0700-x

49. Ubuka T, Ueno M, Ukena K, Tsutsui K. Developmental changes in gonadotropin-inhibitory hormone in the Japanese quail (Coturnix japonica) hypothalamo-hypophysial system. J Endocrinol (2003) 178:311-8. doi:10.1677/ joe.0.1780311

50. Bentley GE, Perfito N, Ukena K, Tsutsui K, Wingfield JC. Gonadotropininhibitory peptide in song sparrows (Melospiza melodia) in different reproductive conditions, and in house sparrows (Passer domesticus) relative to chickengonadotropin-releasing hormone. J Neuroendocrinol (2003) 15:794-802. doi: 10.1046/j.1365-2826.2003.01062.x

51. Kriegsfeld LJ, Mei DF, Bentley GE, Ubuka T, Mason AO, Inoue K, et al. Identification and characterization of a gonadotropin-inhibitory system in the brains of mammals. Proc Natl Acad Sci U S A (2006) 103:2410-5. doi:10.1073/pnas.0511003103

52. Legagneux K, Bernard-Franchi G, Poncet F, La Roche A, Colard C, Fellmann $\mathrm{D}$, et al. Distribution and genesis of the RFRP-producing neurons in the rat brain: comparison with melanin-concentrating hormone- and hypocretincontaining neurons. Neuropeptides (2009) 43:13-9. doi:10.1016/j.npep.2008. 11.001

53. Sharp PJ, Talbot RT, Main GM, Dunn IC, Fraser HM, Huskisson NS. Physiological roles of chicken LHRH-I and -II in the control of gonadotrophin release in the domestic chicken. J Endocrinol (1990) 124:291-9. doi:10.1677/ joe.0.1240291

54. Ubuka T, Bentley GE. Identification, localization, and regulation of passerine GnRH-I messenger RNA. J Endocrinol (2009) 201:81-7. doi:10.1677/JOE-080508

55. Ubuka T, Bentley GE. Neuroendocrine control of reproduction in birds. In: Norris DO, Lopez KH, editors. Hormones and Reproduction of Vertebrates-Vol. 4: Birds. London: Academic Press (2011). p. 1-25.

56. Ubuka T, Cadigan PA, Wang A, Liu J, Bentley GE. Identification of European starling GnRH-I precursor mRNA and its seasonal regulation. Gen Comp Endocrinol (2009) 162:301-6. doi:10.1016/j.ygcen.2009.04.001

57. Ubuka T, Bentley GE, Tsutsui K. Neuroendocrine regulation of gonadotropin secretion in seasonally breeding birds. Front Neurosci (2013) 7:38. doi:10.3389/ fnins. 2013.00038

58. Miyamoto K, Hasegawa $Y$, Nomura M, Igarashi M, Kangawa K, Matsuo $\mathrm{H}$. Identification of the second gonadotropin-releasing hormone in chicken hypothalamus: evidence that gonadotropin secretion is probably controlled by two distinct gonadotropin-releasing hormones in avian species. Proc Natl Acad Sci U S A (1984) 81:3874-8. doi:10.1073/pnas.81. 12.3874

59. Millar RP. GnRH II and type II GnRH receptors. Trends Endocrinol Metab (2003) 14:35-43. doi:10.1016/S1043-2760(02)00016-4

60. Maney DL, Richardson RD, Wingfield JC. Central administration of chicken gonadotropin-releasing hormone-II enhances courtship behavior in a female sparrow. Horm Behav (1997) 32:11-8. doi:10.1006/hbeh.1997.1399

61. Temple JL, Millar RP, Rissman EF. An evolutionarily conserved form of gonadotropin-releasing hormone coordinates energy and reproductive behavior. Endocrinology (2003) 144:13-9. doi:10.1210/en.2002-220883

62. Barnett DK, Bunnell TM, Millar RP, Abbott DH. Gonadotropin-releasing hormone II stimulates female sexual behavior in marmoset monkeys. Endocrinology (2006) 147:615-23. doi:10.1210/en.2005-0662 
63. Ubuka T, Mukai M, Wolfe J, Beverly R, Clegg S, Wang A, et al. RNA interference of gonadotropin-inhibitory hormone gene induces arousal in songbirds. PLoS One (2012) 7:e30202. doi:10.1371/journal.pone.0030202

64. Rizwan MZ, Poling MC, Corr M, Cornes PA, Augustine RA, Quennell JH, et al. RFamide-related peptide-3 receptor gene expression in $\mathrm{GnRH}$ and kisspeptin neurons and GnRH-dependent mechanism of action. Endocrinology (2012) 153:3770-9. doi:10.1210/en.2012-1133

65. Bentley GE, Jensen JP, Kaur GJ, Wacker DW, Tsutsui K, Wingfield JC. Rapid inhibition of female sexual behavior by gonadotropin-inhibitory hormone $(\mathrm{GnIH})$. Horm Behav (2006) 49:550-5. doi:10.1016/j.yhbeh.2005.12.005

66. Johnson MA, Tsutsui K, Fraley GS. Rat RFamide-related peptide-3 stimulates GH secretion, inhibits LH secretion, and has variable effects on sex behavior in the adult male rat. Horm Behav (2007) 51:171-80. doi:10.1016/j.yhbeh.2006. 09.009

67. Ubuka T, Ukena K, Sharp PJ, Bentley GE, Tsutsui K. Gonadotropin-inhibitory hormone inhibits gonadal development and maintenance by decreasing gonadotropin synthesis and release in male quail. Endocrinology (2006) 147:1187-94. doi:10.1210/en.2005-1178

68. Ducret E, Anderson GM, Herbison AE. RFamide-related peptide-3, a mammalian gonadotropin-inhibitory hormone ortholog, regulates gonadotropinreleasing hormone neuron firing in the mouse. Endocrinology (2009) 150:2799-804. doi:10.1210/en.2008-1623

69. Wu M, Dumalska I, Morozova E, van den Pol AN, Alreja M. Gonadotropin inhibitory hormone inhibits basal forebrain vGluT2-gonadotropin-releasing hormone neurons via a direct postsynaptic mechanism. J Physiol (2009) 587:1401-11. doi:10.1113/jphysiol.2008.166447

70. Ciccone NA, Dunn IC, Boswell T, Tsutsui K, Ubuka T, Ukena K, et al. Gonadotrophin inhibitory hormone depresses gonadotrophin alpha and follicle-stimulating hormone beta subunit expression in the pituitary of the domestic chicken. J Neuroendocrinol (2004) 16:999-1006. doi:10.1111/j.13652826.2005.01260.x

71. Gibson EM, Humber SA, Jain S, Williams WP III, Zhao S, Bentley GE, et al. Alterations in RFamide-related peptide expression are coordinated with the preovulatory luteinizing hormone surge. Endocrinology (2008) 149:4958-69. doi:10.1210/en.2008-0316

72. Sari IP, Rao A, Smith JT, Tilbrook AJ, Clarke IJ. Effect of RF-amide-related peptide- 3 on luteinizing hormone and follicle-stimulating hormone synthesis and secretion in ovine pituitary gonadotropes. Endocrinology (2009) 150:5549-56. doi:10.1210/en.2009-0775

73. Kadokawa H, Shibata M, Tanaka Y, Kojima T, Matsumoto K, Oshima K, et al. Bovine C-terminal octapeptide of RFamide-related peptide-3 suppresses luteinizing hormone $(\mathrm{LH})$ secretion from the pituitary as well as pulsatile $\mathrm{LH}$ secretion in bovines. Domest Anim Endocrinol (2009) 36:219-24. doi:10.1016/ j.domaniend.2009.02.001

74. Murakami M, Matsuzaki T, Iwasa T, Yasui T, Irahara M, Osugi T, et al. Hypophysiotropic role of RFamide-related peptide-3 in the inhibition of $\mathrm{LH}$ secretion in female rats. J Endocrinol (2008) 199:105-12. doi:10.1677/JOE-080197

75. Smith JT, Young IR, Veldhuis JD, Clarke IJ. Gonadotropin-inhibitory hormone $(\mathrm{GnIH})$ secretion into the ovine hypophyseal portal system. Endocrinology (2012) 153:3368-75. doi:10.1210/en.2012-1088

76. Anjum S, Krishna A, Sridaran R, Tsutsui K. Localization of gonadotropinreleasing hormone $(\mathrm{GnRH})$, gonadotropin-inhibitory hormone $(\mathrm{GnIH})$, kisspeptin and GnRH receptor and their possible roles in testicular activities from birth to senescence in mice. J Exp Zool A Ecol Genet Physiol (2012) 317:630-44. doi:10.1002/jez.1765

77. Bronson FH. Mammalian Reproductive Biology. Chicago: University of Chicago Press (1990).

78. Wilson FE. Neither retinal nor pineal photoreceptors mediate photoperiodic control of seasonal reproduction in American tree sparrows (Spizella arborea). J Exp Zool (1991) 259:117-27. doi:10.1002/jez.1402590114

79. Juss TS, Meddle SL, Servant RS, King VM. Melatonin and photoperiodic time measurement in Japanese quail (Coturnix coturnix japonica). Proc Biol Sci (1993) 254:21-8. doi:10.1098/rspb.1993.0121

80. Ohta M, Kadota C, Konishi H. A role of melatonin in the initial stage of photoperiodism in the Japanese quail. Biol Reprod (1989) 40:935-41. doi:10.1095/biolreprod40.5.935

81. Guyomarc'h C, Lumineau S, Vivien-Roels B, Richard J, Deregnaucourt S. Effect of melatonin supplementation on the sexual development in European quail
(Coturnix coturnix). Behav Processes (2001) 53:121-30. doi:10.1016/S03766357(01)00133-4

82. Rozenboim I, Aharony T, Yahav S. The effect of melatonin administration on circulating plasma luteinizing hormone concentration in castrated White Leghorn roosters. Poult Sci (2002) 81:1354-9.

83. Greives TJ, Kingma SA, Beltrami G, Hau M. Melatonin delays clutch initiation in a wild songbird. Biol Lett (2012) 8:330-2. doi:10.1098/rsbl.2011.1100

84. Ubuka T, Bentley GE, Ukena K, Wingfield JC, Tsutsui K. Melatonin induces the expression of gonadotropin-inhibitory hormone in the avian brain. Proc Natl Acad Sci U S A (2005) 102:3052-7. doi:10.1073/pnas.0403840102

85. Underwood H, Binkley S, Siopes T, Mosher K. Melatonin rhythms in the eyes, pineal bodies, and blood of Japanese quail (Coturnix coturnix japonica). Gen Comp Endocrinol (1984) 56:70-81. doi:10.1016/0016-6480(84)90063-7

86. Chowdhury VS, Yamamoto K, Ubuka T, Bentley GE, Hattori A, Tsutsui K. Melatonin stimulates the release of gonadotropin-inhibitory hormone by the avian hypothalamus. Endocrinology (2010) 151:271-80. doi:10.1210/en.20090908

87. Revel FG, Saboureau M, Pévet P, Simonneaux V, Mikkelsen JD. RFamide-related peptide gene is a melatonin-driven photoperiodic gene. Endocrinology (2008) 149:902-12. doi:10.1210/en.2007-0848

88. Mason AO, Duffy S, Zhao S, Ubuka T, Bentley GE, Tsutsui K, et al. Photoperiod and reproductive condition are associated with changes in RFamide-related peptide (RFRP) expression in Syrian hamsters (Mesocricetus auratus). J Biol Rhythms (2010) 25:176-85. doi:10.1177/0748730410368821

89. Dardente H, Birnie M, Lincoln GA, Hazlerigg DG. RFamide-related peptide and its cognate receptor in the sheep: cDNA cloning, mRNA distribution in the hypothalamus and the effect of photoperiod. J Neuroendocrinol (2008) 20:1252-9. doi:10.1111/j.1365-2826.2008.01784.x

90. Smith JT, Coolen LM, Kriegsfeld LJ, Sari IP, Jaafarzadehshirazi MR, Maltby M, et al. Variation in kisspeptin and RFamide-related peptide (RFRP) expression and terminal connections to gonadotropin-releasing hormone neurons in the brain: a novel medium for seasonal breeding in the sheep. Endocrinology (2008) 149:5770-82. doi:10.1210/en.2008-0581

91. Gingerich S, Wang X, Lee PK, Dhillon SS, Chalmers JA, Koletar MM, et al. The generation of an array of clonal, immortalized cell models from the rat hypothalamus: analysis of melatonin effects on kisspeptin and gonadotropininhibitory hormone neurons. Neuroscience (2009) 162:1134-40. doi:10.1016/ j.neuroscience.2009.05.026

92. Chand D, Lovejoy DA. Stress and reproduction: controversies and challenges. Gen Comp Endocrinol (2011) 171:253-7. doi:10.1016/j.ygcen.2011.02.022

93. Calisi RM, Rizzo NO, Bentley GE. Seasonal differences in hypothalamic EGR1 and GnIH expression following capture-handling stress in house sparrows (Passer domesticus). Gen Comp Endocrinol (2008) 157:283-7. doi:10.1016/j. ygcen.2008.05.010

94. McGuire NL, Koh A, Bentley GE. The direct response of the gonads to cues of stress in a temperate songbird species is season-dependent. PeerJ (2013) 1:e139. doi:10.7717/peerj.139

95. Kirby ED, Geraghty AC, Ubuka T, Bentley GE, Kaufer D. Stress increases putative gonadotropin inhibitory hormone and decreases luteinizing hormone in male rats. Proc Natl Acad Sci U S A (2009) 106:11324-9. doi:10.1073/pnas. 0901176106

96. Calisi RM, Díaz-Muñoz SL, Wingfield JC, Bentley GE. Social and breeding status are associated with the expression of GnIH. Genes Brain Behav (2011) 10:557-64. doi:10.1111/j.1601-183X.2011.00693.x

97. Delville Y, Sulon J, Hendrick JC, Balthazart J. Effect of the presence of females on the pituitary-testicular activity in male Japanese quail (Coturnix coturnix japonica). Gen Comp Endocrinol (1984) 55:295-305. doi:10.1016/0016-6480(84) 90115-1

98. Cornil CA, Stevenson TJ, Ball GF. Are rapid changes in gonadal testosterone release involved in the fast modulation of brain estrogen effects? Gen Comp Endocrinol (2009) 163:298-305. doi:10.1016/j.ygcen.2009.04.029

Conflict of Interest Statement: The authors declare that the research was conducted in the absence of any commercial or financial relationships that could be construed as a potential conflict of interest.

Received: 11 December 2013; accepted: 14 January 2014; published online: 27 January 2014. 
Citation: Ubuka T, Son YL, Tobari Y, Narihiro M, Bentley GE, Kriegsfeld LJ and Tsutsui $K$ (2014) Central and direct regulation of testicular activity by gonadotropin-inhibitory hormone and its receptor. Front. Endocrinol. 5:8. doi: 10.3389/fendo.2014.00008

This article was submitted to Experimental Endocrinology, a section of the journal Frontiers in Endocrinology.
Copyright (c) 2014 Ubuka, Son, Tobari, Narihiro, Bentley, Kriegsfeld and Tsutsui. This is an open-access article distributed under the terms of the Creative Commons Attribution License (CC BY). The use, distribution or reproduction in other forums is permitted, provided the original author(s) or licensor are credited and that the original publication in this journal is cited, in accordance with accepted academic practice. No use, distribution or reproduction is permitted which does not comply with these terms. 